FOOL'S CORNER

\title{
A summer financial makeover
}

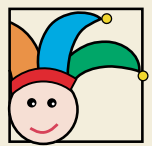

Tom Jacobs, of the Internet site Motley Fool (http://www.fool. com/), provides his angle on biotechnology investments. As Jacobs points out, "Industry insiders may know about biotechnology, but (as the song should go) 'it don't mean a thing, if you haven't learned sound investing principles." Read on and become "Foolishly" informed". He can be contacted about biotechnology and investing at TomJ@Fool.com. Jacobs cannot give individual investment advice but welcomes any.

Let's have a heart to heart. We love delving deeply into the DNA (now there's a turn of phrase!) of biotechnology investing each month with interim president Paisley McTort and the Sitting Pretty Investment Club. But it begs one question: should we be investing in individual companies at all?

We at Fool.com trumpet the eternal truth that potential investors should never even contemplate putting hard-earned money (or even ill-gotten gains) on individual companies until they have completed three simple steps: paying down their credit card debt, emergency-proofing their finances, and investing in their future. Please. Although the steps outlined here are geared to the US financial environment, people in any country can apply the same basic principles.

\section{Step 1: Pay down your high-interest credit card debt}

Shocking, but true: the average American carries $\$ 5,800$ in credit card debt from month to month, and Brits have comparable levels of debt. By making only the minimum payment each month, a cardholder would take 30 years to pay off this debt and cough up an average of $\$ 30,000$ in interest—straight into the lender's pocket. (My, aren't we all generous?)

The first pre-investing rule of thumb: pay off your entire balance if you can, and then commit to paying off each month's balance

${ }^{*}$ Nature Biotechnology does not guarantee the veracity, reliability, or completeness of any information provided on this page; it is not responsible for any errors or omissions or for any results obtained from the use of such information; it will not be liable for any loss, damage, or investment decision arising from a reader's reliance on the information provided. in full when the bill arrives. If you must carry a balance, call your credit card company and politely suggest that you will move your balance to another company's card if they do not lower your interest rate. Shoot for a percentage rate in the low teens (or even in single digits, but good luck!) and act on your threat if they refuse. Then, bite off your balance in pieces. Lather, rinse, and repeat until your debt is paid off. You can do it.

\section{Step 2: Emergency-proof your finances}

Most people should maintain a rainy day fund of three to six months of living expenses, although the exact amount should vary according to how many people depend on your income or if your surname is Knievel (as in stuntman Evel) and you are following in your father's tread marks. Some consider the equity in their home an emergency fund, but we strongly caution against that line of

\section{Using your property as fallback is akin to using a credit card to pay for your living expenses- except that your mortgage carries a lower interest rate}

thought. Using your property as fallback is akin to using a credit card to pay for your living expenses-except that your mortgage carries a lower interest rate.

Most homeowners' number one source of wealth is their home itself. It's far better to maintain a rainy day fund stashed in a money market fund, bank certificate of deposit, or high-interest online bank account, and leave the house to your kids should your next stunt motorcycle gig go awry.

\section{Step 3: Invest in your future}

Hardly a day passes without more news that people are not saving enough for their retirement, in part because fewer people are now covered by traditional employer-paid pension schemes. Added to that is the troubling fact that government pension schemes (Social Security in the United States and state pensions elsewhere), which have uncertain futures themselves, will not provide enough to see you through your dotage. For many people working today, a company $401(\mathrm{k})$ (in the United States) or pension (in the United Kingdom) plan will be their pri- mary source of income during retirement. You contribute a certain percentage of your salary (regulated by the government), and your employer almost always graciously matches a part of it. (And that, my friends, is what we in Fooldom call "free money!") Because the pension contributions are deducted from your salary before tax, in effect you make an immediate profit on that investment by an amount equivalent to your tax rate (in the region of $20-40 \%$ for most of us). There is not one biotechnology investment that guarantees that kind of return.

Where to put the money? Your employer or personal pension provider may offer a range of funds. Depending on how far you are from retirement, you will want to have a substantial to very large percentage of your money in a broad stock market index fund, such as one that tracks the Standard \& Poor's 500 in the United States or the FTSE 100 in the United Kingdom. If your company does not offer that, lobby for it. Point out that the vast majority of actively managed funds underperform the plain old stock market index fund.

In the meantime, choose a stock market fund with the broadest range of companies and a low portfolio turnover. If your employer offers its own shares as an option, limit that investment to $20 \%$ of your total pension contribution. (Does the word "Enron" send chills up your spine? Good.)

\section{What next?}

After you pay off The Man (Mr. Visa, that is), stash away a tidy little emergency fund, and are taking full advantage of your employer's retirement plan, count your cents and pennies and open a Roth IRA (United States) or ISA (United Kingdom). Here you can put in up to $\$ 3,000$ (Roth) or $\mathfrak{E 7 , 0 0 0}$ (ISA) each tax year, and the investment will grow, tax free. This is where the fun begins. You can either invest in an index fund, or start your illustrious stock-picking career along with the Sitting Pretty Investment Club.

Libraries of books cover the principles laid out here, and we have written a fair number of those informative texts. I unabashedly offer up the resources of Fool.com for your further reading pleasure. Plug aside, these are unchanging principles: reduce debt, save for a rainy day, and prepare for your retirement. Once you have these financial rooms in order, your house may be ready to make space for individual stocks. We will check out the furniture next month! 